\title{
Anti-Helicobacter Pylori, Anti-Diabetic and Cytotoxicity Activity of Biosynthesized Gold Nanoparticles Using Moricandia Nitens Water Extract
}

\author{
Nadia A. Soliman ${ }^{1}$, Eman H. Ismail ${ }^{1}$, Heba I. Abd El-Moaty ${ }^{2}$, D. Y. Sabry ${ }^{1}$, \\ Mostafa M.H. Khalil ${ }^{*}$ \\ ${ }^{1}$ Chemistry Department, Ain Shams University, Faculty of Science, 11566, Abbassia, \\ Cairo, Egypt. \\ ${ }^{2}$ Medicinal and Aromatic Plants Department, Desert Research Center, El-Mataria, \\ Cairo, Egypt.
}

\begin{abstract}
$\mathbf{T}$ HIS STUDY aims to synthesize gold nanoparticles (AuNPs) using water extract of Moricandia nitens (Viv.) E. A. Durand \& Barratte aerial parts water extract. The presence of various phytochemicals viz. alkaloids, carbohydrates, glycosides, flavonoids, tannins, cumarines, protein and saponins by following standard biochemical methods was investigated. The effect of different parameters such as extract concentration, $\mathrm{pH}$ and temperature on the size and morphology of the gold nanoparticles (AuNPs) were studied. The synthesized gold nanoparticles (AuNPs) were characterized by using UV-Vis spectroscopy, FTIR and XRD. The synthesized nanoparticles were found to be spherical in shape with average size in the range of 5 to $20 \mathrm{~nm}$. The green synthesized GNPs were found to be potent inhibitors of $\alpha$-glucosidase with an $\mathrm{IC}_{50}$ value of $159.3 \mu \mathrm{g} / \mathrm{ml}$ and showed anti-Helicobacter pylori activity against multidrug resistant $H$. pylori strains with an MIC $31.25(\mu \mathrm{g} / \mathrm{ml})$. Furthermore, biogenic AuNPS possess more significant anticancer activity against HepG2 and HCT-116 withIC ${ }_{50}=44.6 \pm 0.8 \mu \mathrm{g} / \mathrm{ml}$ and $\mathrm{IC}_{50}=36 \pm 0.7 \mu \mathrm{g} / \mathrm{ml}$ respectively.
\end{abstract}

Keywords: Moricandia nitens, Anti-Helicobacter pylori, Anti-diabetic, AuNPs, Anticancer activity, HepG2, HCT-116

\section{Introduction}

Natural products such as plant extracts provide unlimited opportunities for new drug discoveries because of unmatched availability of chemical diversity, either as pure compounds or as standardized extracts [1]. These medicinal plants rich with phenolic compounds, alkaloids, diterpenoid, and other compounds which inhibit the development of various microorganisms [2]. Besides these, phytochemicals in the plant extract it act as reducing and capping agent in the reduction of metal ions to metal nanoparticles [3]. The biosynthesis of metal nanoparticles using natural products as plant extracts has received a great attention as a suitable alternative to existing chemical procedures and physical methods $[4,5]$. Green approaches with controlled shape and size have been developed and thereby it can be used as an economic and valuable alternative for the large scale production of metal nanoparticles. Many researchers have reported the biosynthesis of metal nanoparticles by using various plant extracts $[6,7]$.

Gold nanoparticles (AuNPs) have been widely investigated for their immense potential in various biomedical applications such as imaging, photo diagnostics and photo thermal therapy. Early studies showed that AuNPs improved blood glucose level, liver enzymes and pro-inflammatory cytokines causing control of hyperglycemia, which therefore induce the possible role of AuNPs as a cost-effective therapeutic medication in the treatment of diabetes and its complications [8]. It has been reported that AuNPs functionalized with chitosan and liposomes are highly stable in gastric acid, and capable of fusing with bacteria

*Corresponding author e-mail: khali162@yahoo.com

DOI: 10.21608/EJCHEM.2018.3744.1318

(C)2017 National Information and Documentation Centre (NIDOC) 
at physiological $\mathrm{pH}$, making them suitable to treat gastric pathogens such as Helicobacter pylori infections [9]. Several studies reported that AuNPs cause cellular damage to mammalian cells through unintended mechanisms including induction of necrosis and apoptosis [10], An earlier report suggests that the AuNPs can be used in the destruction of cancer cells and act as potential therapeutic agents [11].

Moricandia nitens (Viv.) E. A. Durand \&Barrattebelong's to family Brassicaceae, which is an economically important family for its many food and oil seed crops as well as containing many important ornamental plants and noxious weeds. Crucifers are characterized by the presence of a group of secondary compounds called glucosinolates $[12,13]$.

From the previous studies GC-MS analysis of the aerial parts and roots of $M$. nitens showed the presence of 50 phytochemical constituents form Glucosinolates [13]. Gluclates are a diverse class of S- and N-containing secondary metabolites that are found mainly in members of the Brassicaceae [14]. Glucosinolates play a variety of roles for plant defense responses and cancer prevention. They are relatively nonreactive, hydrophilic, nonvolatile compounds that are stored within plant vacuoles $[15,16]$.

The present study deals with the synthesis and characterization of AuNPs using aqueous extract of Moricandia nitens and their anti-diabetic activity, Anti-Helicobacter pylori activities and cytotoxic effect.

\section{Experimental}

$\mathrm{HAuCl}_{4} \cdot \mathrm{H}_{2} \mathrm{O} \quad 99.9 \%$ was purchased from Aldrich. Moricandia nitens (Viv.) E. A. Durand \&Barratte was collected at full flowering stage from Ageba area, Mersa-Mattruh at April 2016, then the aerial parts were air dried, then grounded to fine powder and kept to be used for different analysis. Preparation of Moricandia nitens aerial parts extract: The plant extract $(2 \% \mathrm{w} / \mathrm{v})$ was prepared by boiling $2.0 \mathrm{~g}$ of dried, well grinded Moricandia nitens arial parts for $20 \mathrm{~min}$, filtrating, and completing to the volume $100 \mathrm{ml}$ deionized water. The extract was freshly prepared for each experiment.

\section{phytochemical screening}

Freshly collected plant of Moricandia nitens aerial parts were dried and then coarsely powdered. One hundred gm of the coarse powder were extracted using deionized water until clearness. The extract was filtered and subjected to qualitative tests for the identification of various phytochemical constituents [17-19]. Presence of alkaloids were assessed using Dragendorff's test [20], while carbohydrates and proteins using Molisch and Biuret tests, respectively [21]. In addition, cardiac glycosides were assessed using Concentrated $\mathrm{H}_{2} \mathrm{SO}_{4}$ test [22], coumarin using alcoholic sodium hydroxide, flavonoids by Pew's tests [23], saponin using Foam [20], tannins by Ferric chloride test and terpenes using Salkowski's test [22]. Moreover, volatile oils were assessed using oil distillation method. All these procedures are underlined by Allen S.E. [24].

\section{Anti-diabetic potential Evolution}

Determination of $\alpha$-glucosidase inhibitory activity: The $\alpha$-glucosidase inhibitory activity was measured according to the method described by You, Q. et al. [25]. Briefly $0.1 \mathrm{mg}$ of each sample or acarbose at different concentration (1000- $1.95 \mu \mathrm{g} / \mathrm{ml}$ ) was incubated with $500 \mu \mathrm{l}$ of $1.0 \mathrm{U} / \mathrm{ml} \alpha$-glucosidase solution in $100 \mathrm{mM}$ phosphate buffer $(100 \mathrm{mM}, \mathrm{pH} 6.8)$ at $37{ }^{\circ} \mathrm{C}$ for 15 minutes. Thereafter, $250 \mu \mathrm{l}$ of $\mathrm{p}$ - nitrophenyl glucopyranoside (pNPG) $(5 \mathrm{mM})$ in the same buffer was added and the reaction mixture was further incubated at $37{ }^{\circ} \mathrm{C}$ for $20 \mathrm{~min}$. The absorbance of the released p-nitrophenol was measured at $405 \mathrm{~nm}$ using a microplate reader (BioTeK Instruments, Inc., Winooski, VT). The inhibition percentage was calculated using as follow:

$$
\% \text { Inhibition }=\frac{A b s_{\text {control }}-A b s_{\text {Sample }}}{A b s_{\text {Control }}} \times 100
$$

Where, abs control is the absorbance of the control reaction (containing all reagents except the test sample) and abs sample is the absorbance of the test sample. The $\mathrm{IC}_{50}$ value was defined as the concentration of a-glucoside inhibitor to inhibit $50 \%$ of its activity under the assay condition.

Helicobacter pylori activity assay

Determination of the minimal inhibitory concentration (MIC)

Antibacterial activity of tested compound against helicobacter pylori was determined by a micro-well dilution method described by Bonacorsi, C. et al. [26].

The inoculum of helicobacter pylori was prepared and the suspension was adjusted to $10^{6}$ 
$\mathrm{CFU} / \mathrm{ml}$. The compounds under investigation and standard drug (Clarithromycin) were prepared in dimethyl sulfoxide (DMSO) and subsequent twofold dilutions (1000-0.03 $\mu \mathrm{g} \mathrm{g}$ ) were prepared in a 96 - well plate. Each well of the microplate included $40 \mu 1$ of the growth medium (Brain Heart (BHI) plus 10\% fetal bovine serum (FBS), $10 \mu 1$ of inoculum and $50 \mu \mathrm{l}$ of the diluted compounds. The Clarithromycin and DMSO are used as positive controls, respectively. The plates were incubated at $37{ }^{\circ} \mathrm{C}$ for 3 days, in $5 \% \mathrm{O}_{2}, 10 \% \mathrm{CO}_{2}$, and $85 \% \mathrm{~N}_{2}$ atmosphere. After that ,40 $\mu \mathrm{l}$ of 3-(4,5-dimethyl-thiazol-2-yl)-2,5-diphenyltetrazolium bromide(MTT) at a final concentration $0.5 \mathrm{mg} / \mathrm{ml}$ freshly prepared in water was added to each well and incubated for $30 \mathrm{~min}$. The change to purple color indicated that the bacteria were biologically active. The inhibition percentage was calculated using the formula:

$$
\% \text { Inhibition }=\frac{A b s_{\text {control }}-A b s_{\text {Sample }}}{A b s_{\text {Control }}} \times 100
$$

The concentration of samples (Inhibitor) required for $90 \%$ of inhibition (MIC 90) was determined to form corresponding dose-response curves. The MIC was taken to the lowest concentration, where no change of color of MTT was determined using an automatic reader at 620 $\mathrm{nm}$. The MITT were done in triplicate.

\section{The cytotoxicity assay}

The cytotoxicity assay performed according to the micro culture MTT method with slight modifications [27]. The cells were harvested $\left(1.5 \times 10^{4}\right.$ cells/well $)$ and inoculated in 96well microtiter plates. They were washed with phosphate-buffered saline (PBS) and the cultured cells were then inoculated with and without the sample $(1 \mathrm{mg} / \mathrm{ml})$. After $72 \mathrm{~h}$ of incubation, the medium was aspirated. Ten micro-liters of MTT solution $(5 \mathrm{mg} / \mathrm{ml}$ in PBS, $\mathrm{pH} 7.2$ ) was added to each well and the plates were incubated for $4 \mathrm{~h}$ at $37^{\circ} \mathrm{C}$. After incubation, $100 \mu \mathrm{l}$ of dimethyl sulfoxide (DMSO) was added to the wells followed by gentle shaking to solubilize the formazan dye for $15 \mathrm{~min}$. Absorbance was read at $540 \mathrm{~nm}$ and the surviving cell fraction was calculated. Suramin $(100 \mu \mathrm{M})$ was used as the reference standard for anticancer activity, and $\mathrm{H}_{2} \mathrm{O}_{2}(1 \mathrm{mM})$ was used as the cytotoxic agent against normal liver cell lines. The inhibition of cell viability and COX was calculated using the formula: $\%$ viability $=\mathrm{A}_{t} / \mathrm{A}_{\mathrm{c}}$ $\mathrm{x} 100$, where $A_{t}=$ Absorbance of the test sample and $A_{c}=$ Absorbance of the control sample.

\section{Synthesis of AuNPs Moricandia nitens aqueous} extract:

To synthesize nanoparticles using Moricandia nitens, a certain volume of Moricandia nitens extract was added to $0.05 \mathrm{ml}$ of $\mathrm{HAuCl}_{4}$ at room temperature and the mixture was shacked well then completed to $10 \mathrm{ml}$ with deionized water. The final concentration of $\mathrm{Au}$ was $1.4 \times 10^{-4} \mathrm{M}$. The reduction process of $\mathrm{Au}^{3+}$ to AuNPs was followed by the change in the color of the solution and UV-visible spectroscopy. The nanoparticles prepared at different $\mathrm{pH}$ values, the $\mathrm{pH}$ of the solutions $\left(1.4 \times 10^{-4} \mathrm{M} \mathrm{AuCl}^{4-}\right.$ and $2.6 \mathrm{ml}$ extract in $10 \mathrm{ml}$ flask) were adjusted using $0.1 \mathrm{~N} \mathrm{HCl}$ or 0.1 $\mathrm{N} \mathrm{NaOH}$ solutions.

\section{Characterization of AuNPs \\ $U V$-visible spectral analysis}

The bio-reduction of $\mathrm{AuCl}_{4}^{-}$ions in solution was monitored by measuring the UV-vis spectra of the reacted mixtures at wavelengths between $300-1000 \mathrm{~nm}$ on a $\lambda$-Helios SP Pye- Unicam UVVis spectrophotometer using $10 \mathrm{~mm}$ optical path length quartz cuvettes.

\section{Transmission electron microscopy (TEM)}

The size and morphology of the nanoparticles were examined and the TEM images were obtained on a JEOL-1200JEM. Transmission electron microscopy samples of AuNPs were conducted by placing a drop of the bio-synthesized AuNPs suspension onto carbon coated copper grids and allowing the solvent to evaporate in air.

\section{$X$-Ray Diffraction}

XRD measurement of the AuNPs was done on a Shimadzu XRD-6000 diffractometer operating at a voltage of $40 \mathrm{KV}$ and current of $20 \mathrm{~mA}$ with $\mathrm{Cu} \mathrm{K \alpha}$ radiation. $(\lambda=1.54 \AA)$. Fourier transform infrared (FTIR) spectroscopy: Nicolet 6700 FTIR spectrometer was used to obtain FTIR spectra at room temperature. The bio-reduced chloroauric acid solution was centrifuged at 10,000 rpm for 15 min and the sample was dried and grinded with $\mathrm{KBr}$ in the form of round disk and it was analyzed to get FTIR of capped nanogold. FTIR of Moricandia nitens aerial parts was obtained by grinding dried with $\mathrm{KBr}$.

\section{Results and Discussion}

\section{The phytochemical screening}

The results for preliminary phytochemical screening carried out on the Moricandia nitens, were summarized in Table 1. It showed the presence of flavonoids, carbohydrates, glycosides, 
tannins, coumarins, proteins, fatty acids, phenolic compounds, alkaloids, and saponins while terpenes and volatile oils are absent.

\section{$U V$-visible spectroscopy and TEM Studies}

Effect of Moricandia nitens aerial parts extract concentration: The formation of AuNPs was confirmed by the visual color change from yellow into mauve, purple (or brilliant red color) and green according to size and shape of formed AuNPs as shown in Fig. 1. Synthesis of AuNPs using a constant $\mathrm{HAuCl} 4$ concentration $\left(1.4 \times 10^{-4}\right.$ M) $(5 \times 10-3 \mathrm{w} / \mathrm{v})$ and different concentrations of Moricandia nitens aerial parts extract is followed by Uv-visible spectroscopy measurements. Using low Moricandia nitens extract concentrations $(0.2 \% \mathrm{w} / \mathrm{v})$ a broad band centered at $560 \mathrm{~nm}$ is obtained indicating the formation of AuNPs [28,29]. Increasing the Moricandia nitens extract concentration from $0.2 \mathrm{ml}$ to $2.6 \mathrm{ml}$, the SPR band intensity is found to increase with a blue shift in the band from $560 \mathrm{~nm}$ to $543 \mathrm{~nm}$, this blue shift indicates the formation of uniformly polydispersed spherical shaped nanoparticles, with particle size ranging from 5 to $30 \mathrm{~nm}$.

As shown in TEM images taken for AuNPs synthesized using $0.4 \mathrm{ml}$ of Moricandia nitens aerial parts extract, different nano-shapes (nanotriangles, nano-spheres and nano-hexagons) with different sizes ranging from 10 to $30 \mathrm{~nm}$, while using $2.6 \mathrm{ml}$ of extract the size of the nanoparticles decrease in range 5-20 nm with spherical shape (Fig. 2). Further increase of the extract concentration the SPR band starts to decrease again indicating the agglomeration of nanoparticles by secondary reduction phenomenon between capping phytochemicals on the surface of the preformed nuclei [30-32]

\section{Effect of contact time}

The rate of the Moricandia nitens aerial parts extract mediated biosynthesis of AuNPs is studied by monitoring the absorption intensity of the SPR band at $537 \mathrm{~nm}$ at time intervals of 5 min for 40 min. As shown in Fig.3, the bio-reduction started within $2 \mathrm{~min}$. and increased dramatically in the first $20 \mathrm{~min}$. indicating a high initial reaction rate after that only slight increase in the absorption intensity was observed, after $35 \mathrm{~min}$ there was nearly no change in the absorption intensity indicating that the reaction was completed within $40 \mathrm{~min}$.

\section{Effect of extract $p H$}

The $\mathrm{pH}$ of the extract used in the biosynthesis of AuNPs is a critical factor affecting the size, shape and composition of the nanoparticles. With the help of Uv-vis spectroscopy and TEM analysis the impact of Moricandia nitens aerial parts extract $\mathrm{pH}$ on biosynthesis of AuNPs is studied. At $\mathrm{pH} 3$ abroad SPR band with undefined peak is absents increasing $\mathrm{pH}$ from 4 to 8 the SPR absorption band increase accompanied with a blue shift in the wavelength from $545 \mathrm{~nm}$ to $536 \mathrm{~nm}$ suggesting the formation of smaller nanoparticles [33]. Increasing $\mathrm{pH}$ of extract solution, the SPR decrease with change in SPR maximum indicating that at $\mathrm{pH}$ higher than 8 affect the reducing ability of the extract.

These results were consistent with several studies which reported that at low $\mathrm{pH}$, the gold nanoparticles prefer to aggregate to form larger nanoparticles rather than to nucleate and form new nanoparticles (aggregation of nanoparticles is favored over the nucleation). However, higher $\mathrm{pH}$ facilitates the nucleation and subsequent formation of large number of nanoparticles

TABLE 1. The preliminary screening of water aerial parts extract of Moricandia nitens.

\begin{tabular}{ccc}
\hline Phytochemical compound & Results \\
\hline Alkaloids & + \\
Carbohydrates & + & + \\
Glycosides & + \\
Flavonoids & + \\
Tannins & + \\
Cumarines & + \\
Protein & + \\
Saponins & - \\
Terpenes & + \\
Fatty acids & - \\
\hline
\end{tabular}

Egypt. J. Chem. 61, No. 4 (2018) 


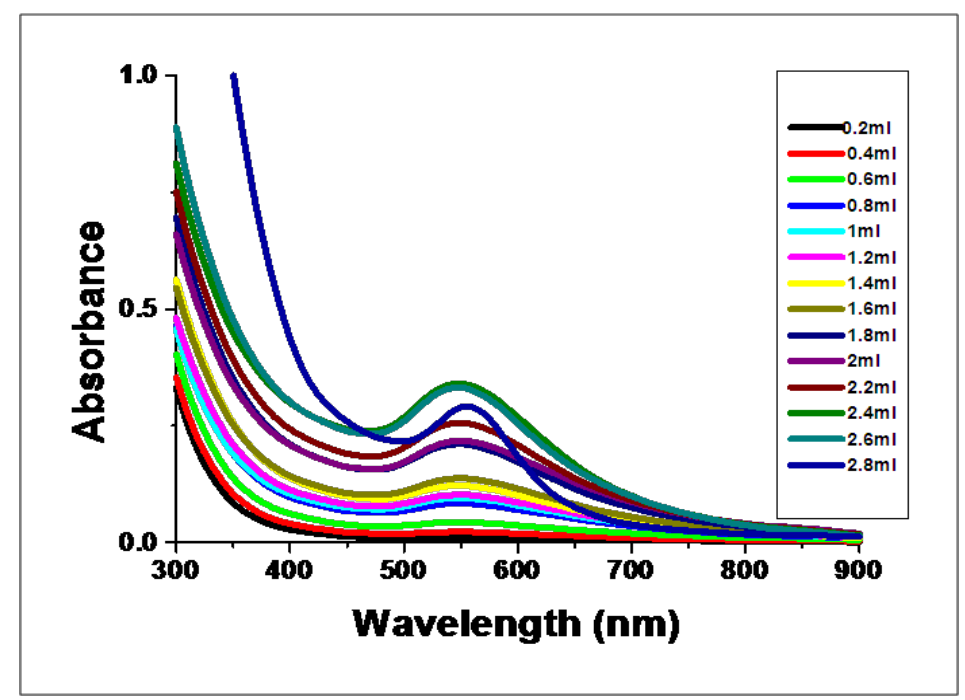

Fig. 1. Uv-vis spectra of gold nanoparticles using constant $\mathrm{HAuCl} 4$ concentration $\left(1.4 \times 10^{-4} \mathrm{M}\right)$ and different Moricandia nitens aerial parts extract concentrations.

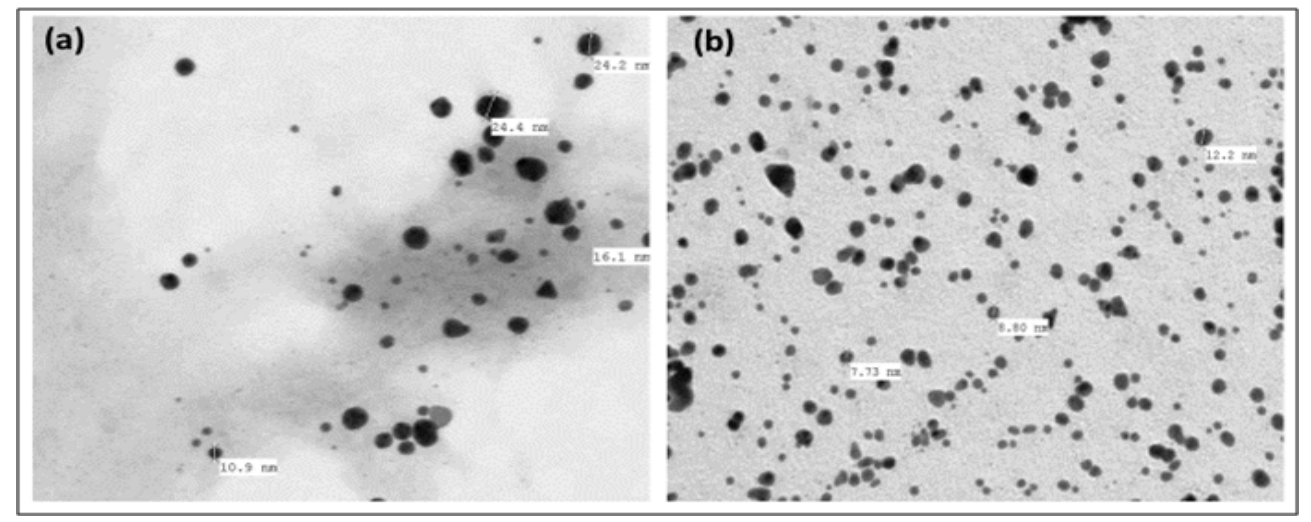

Fig. 2. TEM images of AuNPs synthesized using HAuCl4 $\left(1.4 \times 10^{-4} \mathrm{M}\right)$ and (a) $0.4 \mathrm{ml}$ and (b) $2.6 \mathrm{ml}$ of Moricandia nitens aerial parts extract.

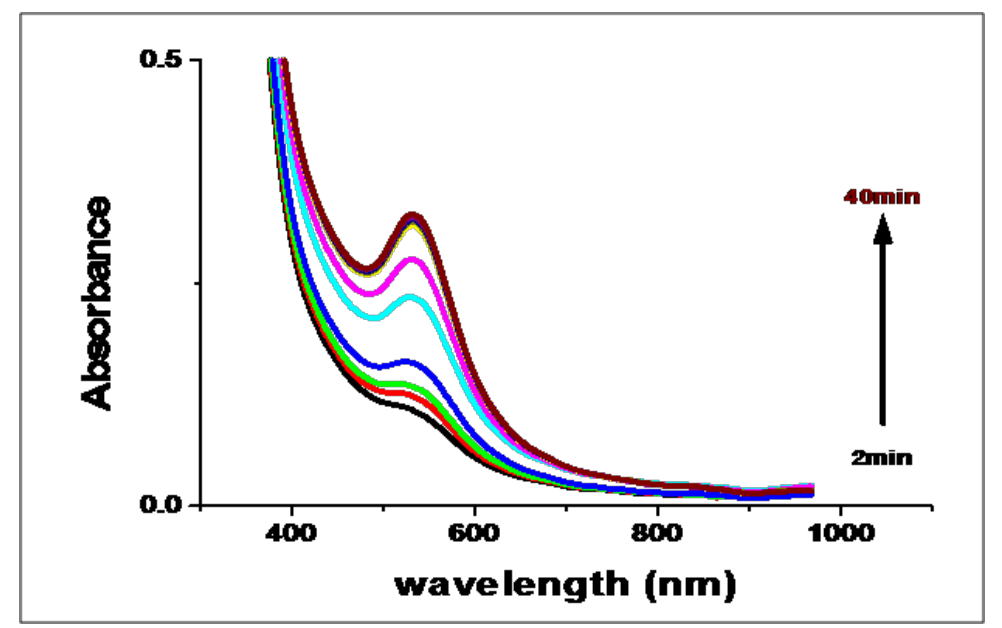

Fig. 3. UV-Vis spectra recorded from reduction of $1.4 \times 10^{-4} \mathrm{M} \mathrm{HAuCl}_{4}$ using $2.6 \mathrm{ml}$ of Moricandia nitens aerial parts extract at various time intervals of 5 minutes for $\mathbf{4 0}$ minutes. 


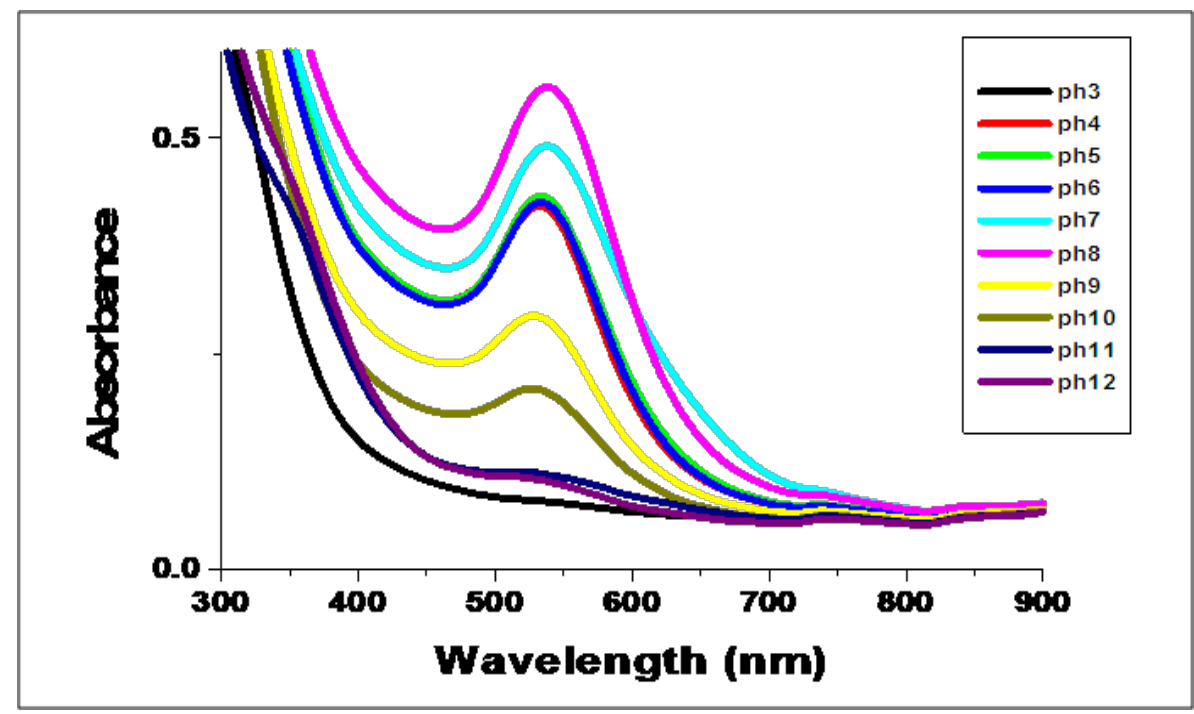

Fig. 4. Uv-Vis spectra of AuNP synthesized using $2.6 \mathrm{ml}$ of Moricandia nitens aerial parts extract using $\mathrm{HAuCl}_{4}$ at different $\mathrm{pH}$ of the extract (pH 3-12).
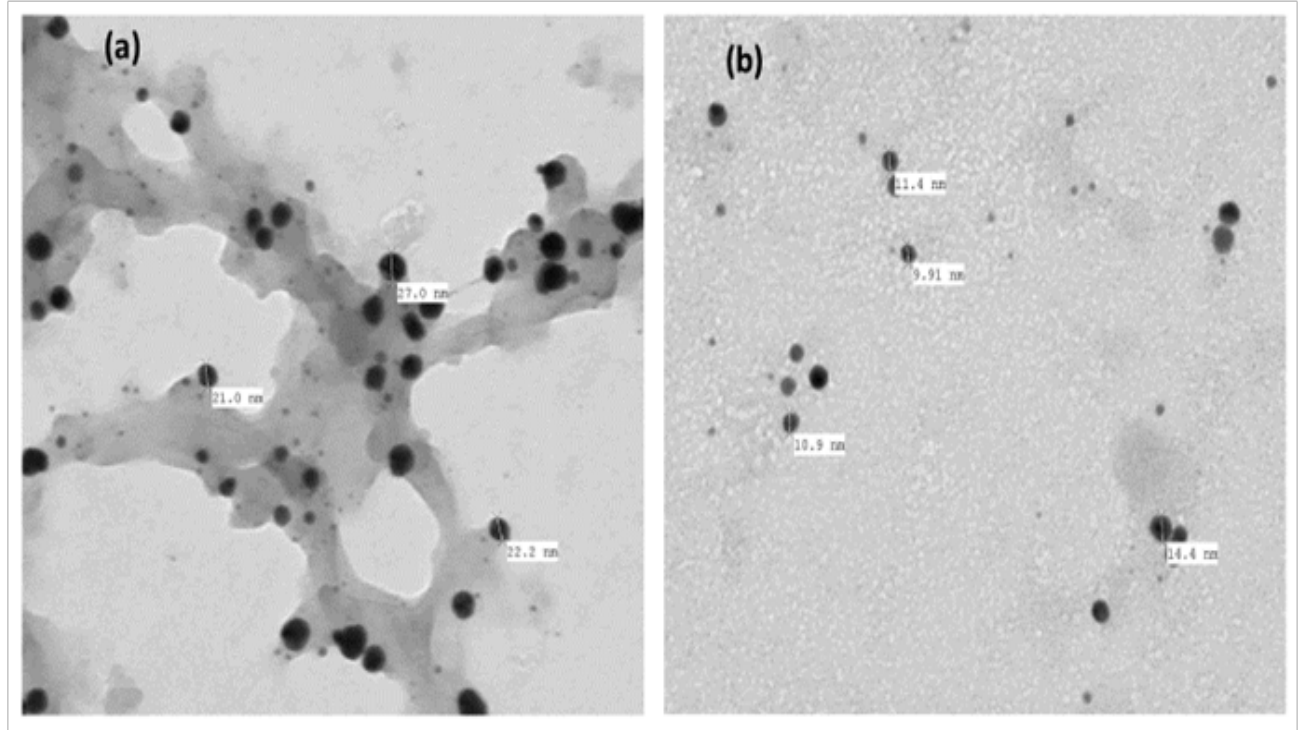

Fig. 5. TEM images of AuNPs (a) at pH4 and (b) at pH8 of plant extract.

with smaller diameter, also more functional groups (carbonyl and hydroxyl) are available for gold binding thus, a higher number of $\mathrm{Au}$ (III) complexes would bind to the biomolecules at the same time [34-36]. Increasing alkalinity of the surrounding media above $\mathrm{pH} 8$ induced a change in the electron density on the surface of AuNPs so it affects surface plasmon band and band intensity decreased.

Effect of reaction temperature on AuNPs synthesis

Figure 6 shows the effect of temperature in the nanoparticles synthesis. The SPR of nanoparticles increases with increasing the reaction temperature using Moricandia nitens extract with blue shifted form $556 \mathrm{~nm}$ to $530 \mathrm{~nm}$ indicating formation of small size of AuNPs with increasing reaction temperature. The higher rate of reduction was occurred at higher temperature due to the consumption of gold ions in the formation of nuclei whereas the secondary reduction was stopped on the surface preformed nuclei [30].

\section{$X$-Ray diffraction study}

The green-synthesized nanoparticles were clearly analyzed using XRD measurements. 


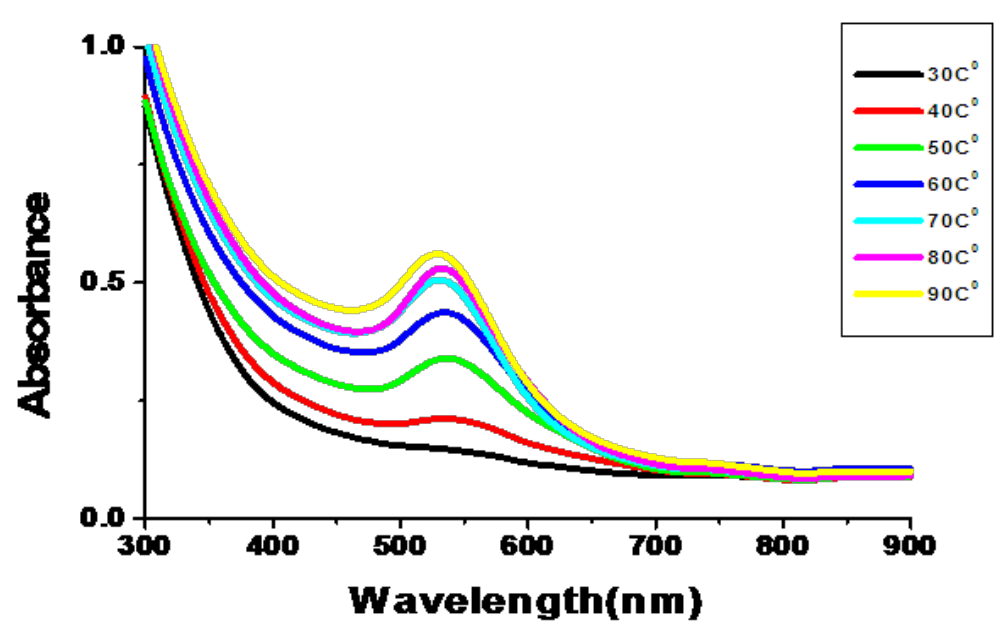

Fig. 6. Uv-vis spectra of AuNPs as a function of time.

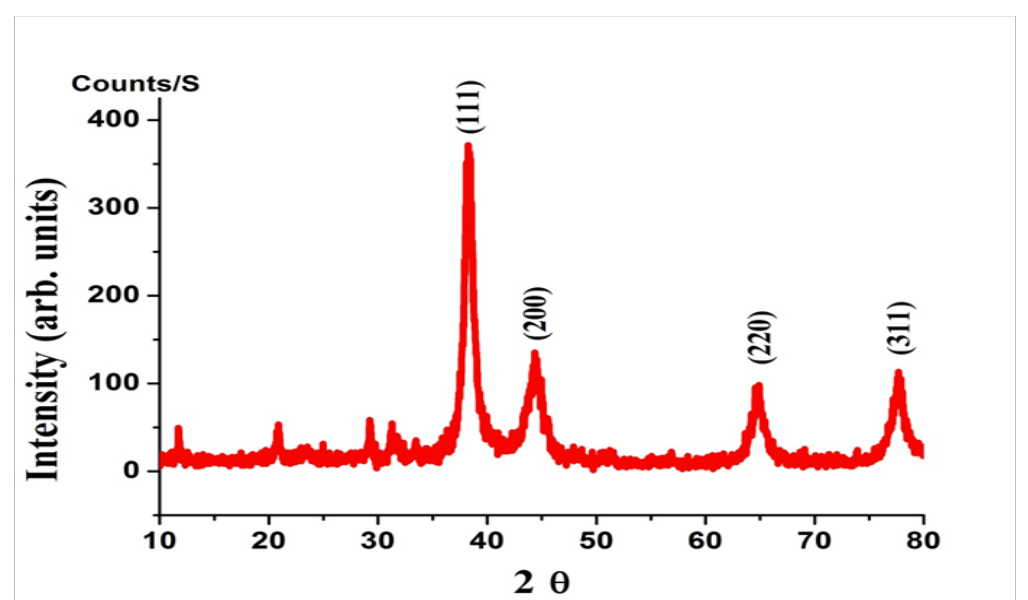

Fig. 7. The X-ray diffraction (XRD) patterns of AuNPs synthesized using Moricandia nitens aerial parts extract.

Figure 7 shows the XRD patterns of the AuNPs prepared using Moricandia nitens extract. The XRD patterns revealed that AuNPs corresponded to the crystalline gold face centered cubic phase. The four prominent Bragg reflections obtained at $2 \theta=38.33^{\circ}(111), 44.35^{\circ}(200), 64.83^{\circ}(220)$, and $77.73^{\circ}(311)$ are identical with those reported for the standard gold metal $\left(\mathrm{Au}^{0}\right)$ (Joint Committee on Powder Diffraction Standards-JCPDS, USA). The data revealed crystalline nature of AuNPs.

\section{Fourier transform infrared spectroscopy (FTIR)}

FTIR measurements were carried out to identify the possible biomolecules in the Moricandia nitens aerial parts extract responsible for the reduction and the stabilization of the synthesized AuNPs. The FTIR spectrum of the aerial part extract of Moricandia nitens is shown in Fig.8. The absorption bands at $3406.4 \mathrm{~cm}^{-1}$ is associated with $\mathrm{OH}$ (alcohol) stretching. The peaks at 2922.3,
$2852.0 \mathrm{~cm}^{-1}$ are associated with anti-symmetric and symmetric stretching of $\mathrm{CH}_{2}$, respectively. The peak for the carbonyl group was found at 1738.5 $\mathrm{cm}^{-1}$. The synthesized AuNPs revealed a shift in the peaks to $3404.5,2918.3,2849.1$, and $1730.0 \mathrm{~cm}^{-}$ ${ }^{1}$. The highest absorption peak $3404.5 \mathrm{~cm}^{-1}$ reflects that the $\mathrm{OH}$ group might be responsible for the reducing property of the extract.

In vitro $\alpha$-glucosidase enzyme inhibition assay

The in vitro $\alpha$-glucosidase inhibitory studies demonstrated that gold nanoparticles synthesized using Moricandia nitens had $\alpha$-glucosidase inhibitory activity. Gold nanoparticles showed a strong inhibitory potential with an $\mathrm{IC}_{50}=159.3 \mu \mathrm{g} /$ $\mathrm{ml}$, Extract IC50 $>1000 \mu \mathrm{g} / \mathrm{ml}$.The Acarbose, the positive control used in this study, inhibited the activity of $\alpha$-glucosidase with an $\mathrm{IC}_{50}$ value estimated at $30.54 \mu \mathrm{g} / \mathrm{ml}$ (Fig.9). It should be mentioned here that the calculated $\mathrm{IC}_{50}$ values in the current studies is correlated with earlier studies

Egypt. J. Chem. 61, No. 4 (2018) 


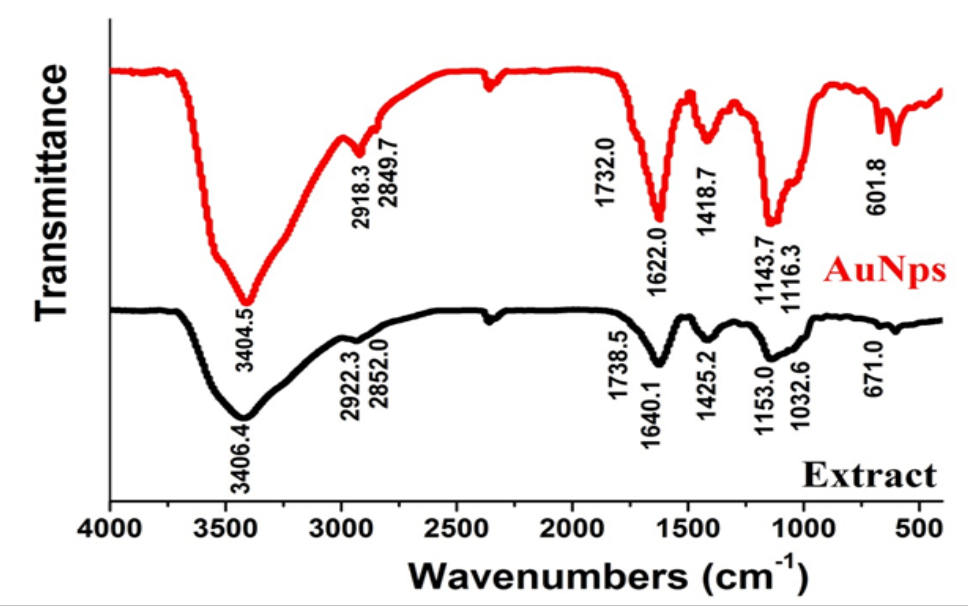

Fig. 8. FTIR of Moricandia nitens extract and capped AuNPs.

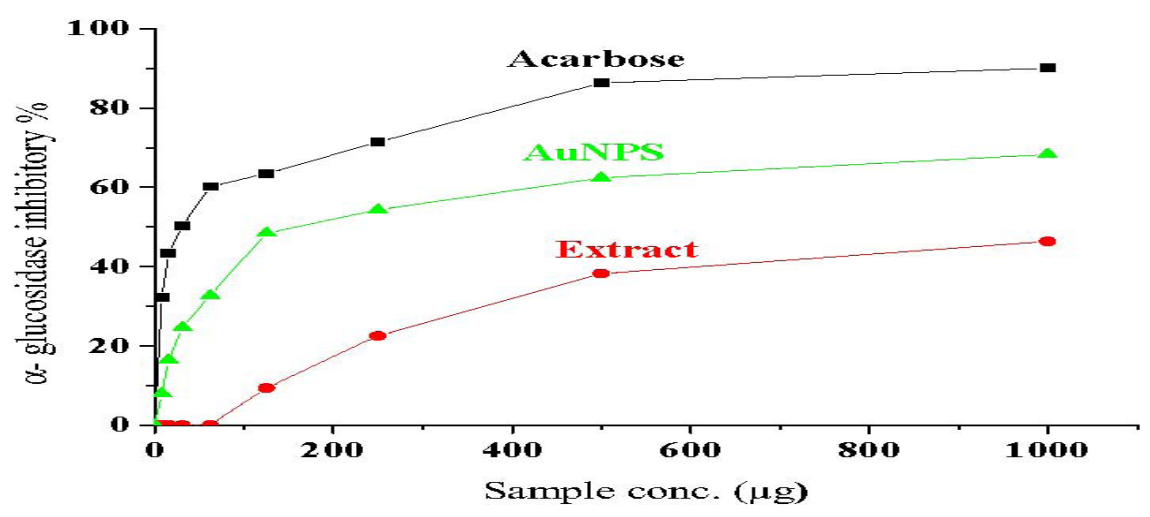

Fig. 9. Anti-diabetic activity of Acarbose, Moricandia nitens extract and AuNPs.

TABLE 2. Anti-diabetic activity $\left(\mathrm{IC}_{50}\right)$ of Acarbose, extract and AuNPs.

\begin{tabular}{cc}
\hline Sample code: & IC $_{\mathbf{5 0}}$ \\
\hline Acarbose & 30.57 \\
Extract & $>1000$ \\
AuNPs & 159.3 \\
\hline
\end{tabular}

TABLE 3. MIC of Clarithromycin, extract and AuNPs.

\begin{tabular}{cc}
\hline Sample code: & MIC \\
\hline Clarithromycin & $\mathbf{1 . 9 5}$ \\
Extract & $>\mathbf{1 0 0 0}$ \\
AuNPs & $\mathbf{3 1 . 2 5}$ \\
\hline
\end{tabular}

Egypt. J. Chem. 61, No. 4 (2018) 
[37]. The $\mathrm{IC}_{50}$ values of AuNPs of exhibited lower value compared to Moricandia nitens extract which suggest that nanoparticles are potent than plant extract in inhibiting $\alpha$-glucosidase. The strong enzymatic $\alpha$-glucosidase inhibitory activity shown by green synthesized AuNPs is much better than that of plant extract inhibition. It can be proposed that AuNPs synthesized from Moricandia nitens might be a potential resource of $\alpha$-glucosidase inhibitors formulation that may benefit diabetes treatment.

\section{3-9 In Vitro Anti-Helicobacter Pylori Activity.}

MIC90 of AuNPs synthesized using Moricandia nitens for their in vitro anti-H. pylori activity revealed inhibition of the bacterial growth relatively at low concentration than extract at 31.25 and $>1000$ for AuNPS and extract respectively for H. pylori. The AuNPs are effective against H. pylori reflecting that AuNPs could be used as potent anti-H. pylori agents. current studies is correlated with earlier studies [38].
In vitro cytotoxicity of $A u N P S$

The in vitro anticancer efficacy of, AuNP's and aqueous extract of aerial parts confirmed by MTT assay exhibited with $I_{50}=36 \pm 0.7 \mu \mathrm{g} / \mathrm{ml}$ and $I C_{50}=99.8 \pm 1.4 \mu \mathrm{g} / \mathrm{ml}$ for colon carcinoma $(\mathrm{HCT}-116), \mathrm{IC}_{50}=44.6 \pm 0.8 \mu \mathrm{g} / \mathrm{ml}$ and $\mathrm{IC}_{50}$ $=114 \pm 1.4 \mu \mathrm{g} / \mathrm{ml}$. for Hepatocellular carcinoma $(H e p G-2)$ respectively. The results clearly reveal that the Au-NPs exhibited selective cytotoxicity against HCL-116 and HepG2 cancer cells. Form thesis results we can say that nano synthesis gives great support and improvement to plant extract in cytotoxicity activities.

\section{Conclusion}

Our study is the first report on the green synthesis of gold nanoparticles from Moricandia nitens and suggests their strong inhibition of digestive

TABLE 4. Cytotoxicity $\left(\mathrm{IC}_{50}\right)$ of aqueous extract of Moricandia nitens and the nanoparticles.

\begin{tabular}{ccc}
\hline Sample code: & $\mathbf{I C}_{\mathbf{5 0}}=\boldsymbol{\mu g} / \mathbf{m l}(\mathbf{H C T}-\mathbf{1 1 6})$ & IC $_{\mathbf{5 0}}=\boldsymbol{\mu g} / \mathbf{m l}(\mathbf{H e p G}-\mathbf{2})$ \\
\hline Extract & $99.8 \pm 1.4$ & $114 \pm 1.4$ \\
AuNPs & $36 \pm 0.7$ & $44.6 \pm 0.8$ \\
\hline
\end{tabular}

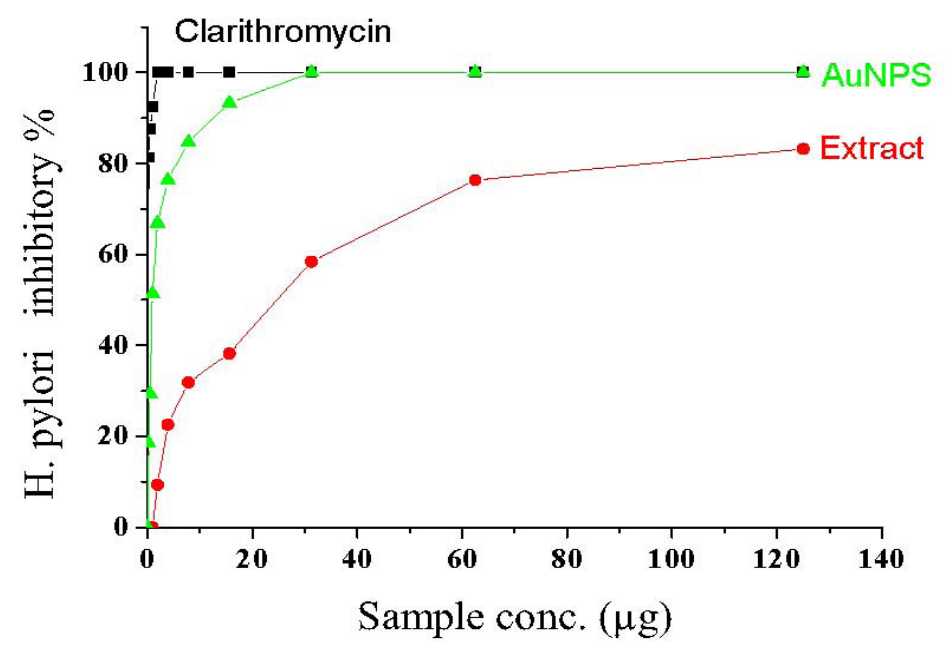

Fig. 10.Anti-Helicobacter pylori Activity of Clarithromycin, Moricandia nitens extract and AuNPs. 


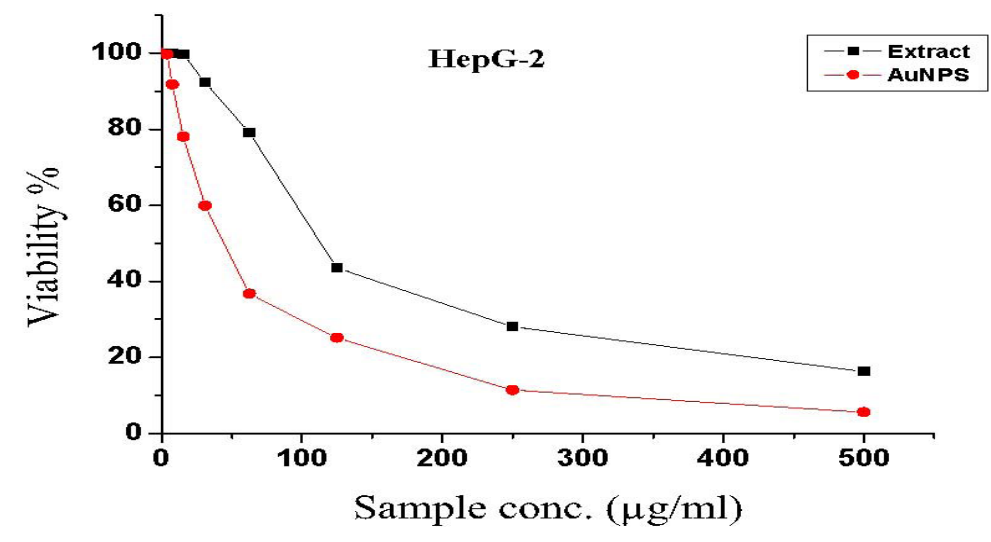

Fig. 11. Cell viability\% of AuNPs prepared using Moricandia nitens extract for Hepatocellular carcinoma (HepG-2).

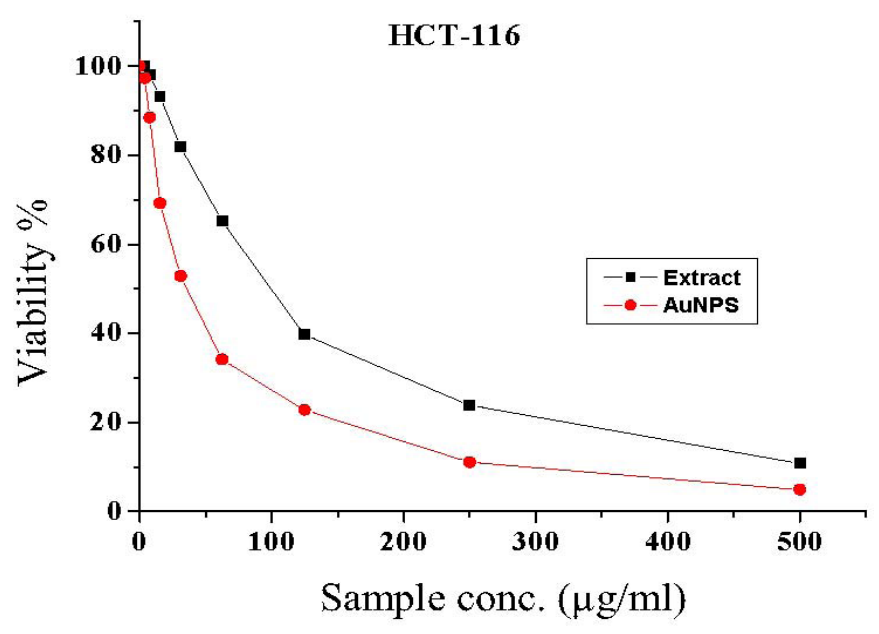

Fig. 12. Cell viability\% of AuNPs prepared using Moricandia nitens extract for colon carcinoma (HCT-116).

enzyme $\alpha$-glucosidase. The efficacy of the gold nanoparticles to inhibit glucosidase and serve as an anti-diabetic agent has been ascertained, exhibited anti-H. pylori activity against multi-drug resistant clinical strains of $\mathrm{H}$. Pylori also synthesized nanoparticles were found to be effective against HepG2 and HCT-116 carcinoma cells.

\section{$\underline{\text { References }}$}

1. Sasidharan, S., Chen, Y., Saravanan, D., Sundram, K. M., \& Latha, L. Y., Extraction, isolation and characterization of bioactive compounds from plants' extracts. African Journal of Traditional, Complementary and Alternative Medicines, 8(1) (2011).

Egypt. J. Chem. 61, No. 4 (2018)
2. Hazarika, D., Phukan, A., Saikia, E., \& Chetia, B., Phytochemical screening and synthesis of silver nanoparticles using leaf extract of Rhynchotechum ellipticum. International Journal of Pharmacy and Pharmaceutical Sciences, 6(1), 672-674 (2014).

3. Swarnalatha, Y., Krishnan, D., \& Rajasekar, S. P. V., Antibacterial activity of biogenic silver nanoparticles from Sphaeranthusam aranthoides. Int J Pharm Pharm Sci, 5(4), 594-596 (2013).

4. Song, J. Y., \& Kim, B. S., Rapid biological synthesis of silver nanoparticles using plant leaf extracts. Bioprocess and Biosystems Engineering, 32(1), 79 (2009). 
5. Chandran, S. P., Chaudhary, M., Pasricha, R., Ahmad, A., \& Sastry, M., Synthesis of gold nanotriangles and silver nanoparticles using Aloe vera plant extract. Biotechnology Progress, 22(2), 577-583 (2006).

6. He, Y., Du, Z., Lv, H., Jia, Q., Tang, Z., Zheng, X., \& Zhao, F., Green synthesis of silver nanoparticles by Chrysanthemum morifolium Ramat. extract and their application in clinical ultrasound gel. International Journal of Nanomedicine, 8 , 1809 (2013).

7. Niraimathi, K. L., Sudha, V., Lavanya, R., \&Brindha, P., Biosynthesis of silver nanoparticles using Alternanthera sessilis (Linn.) extract and their antimicrobial, antioxidant activities. Colloids and Surfaces B: Biointerfaces, 102, 288-291 (2013).

8. Edrees, H. M., Elbehiry, A., \& Elmosaad, Y. M., Hypoglycemic and Anti-Inflammatory Effect of Gold Nanoparticles in Streptozotocin-Induced Type 1 Diabetes in Experimental Rats. International Journal of Diabetes Research, 6(1), 16-23 (2017).

9. Thamphiwatana, S., Gao, W., Pornpattananangkul, D., Zhang, Q., Fu, V., Li, J., \& Zhang, L. Phospholipase A2-responsive antibiotic delivery via nanoparticle-stabilized liposomes for the treatment of bacterial infection. Journal of Materials Chemistry B, 2(46), 8201-8207 (2014).

10. Leite, P. E. C., Pereira, M. R., do Nascimento Santos, C. A., Campos, A. P. C., Esteves, T. M., \& Granjeiro, J. M., Gold nanoparticles do not induce myotube cytotoxicity but increase the susceptibility to cell death. Toxicology in Vitro, 29(5), 819-827 (2015).

11. Mata, R., Nakkala, J. R., \& Sadras, S. R., Polyphenol stabilized colloidal gold nanoparticles from Abutilon indicum leaf extract induce apoptosis in HT-29 colon cancer cells. Colloids and Surfaces B: Biointerfaces, 143, 499-510 (2016).

12. Van Etten $\mathrm{CH}$, Tookey HL. Glucosinolates. In: Rechcigl, M. (Ed.), Naturally Occurring Food Toxicants. CRC Press, Boca Raton, FL, pp.15-30 (1983)

13. Abd El-Moaty, H. I., Bioactive compounds of Moricandia Nitens and its anticancer effect. Indo American Journal of Pharmaceutical Sciences, 3(10), 1283-129 (2016).

14. Fahey, J. W., Zalcmann, A. T., \&Talalay, P.
The chemical diversity and distribution of glucosinolates and isothiocyanates among plants. Phytochemistry, 56(1), 5-51 (2001).

15. Koroleva, O. A., Davies, A., Deeken, R., Thorpe, M. R., Tomos, A. D., \& Hedrich, R., Identification of a new glucosinolate-rich cell type in Arabidopsis flower stalk. Plant Physiology, 124(2), 599-608 (2000).

16. Kelly, P. J., Bones, A., \& Rossiter, J. T., Sub-cellular immunolocalization of the glucosinolate sinigrin in seedlings of Brassica juncea. Planta, 206(3), 370-377 (1998).

17. Brinda P., Sasikala P. and Purushothaman K.K., Pharmacognostic studies on Merugankizhangu. Bulletin in Medical Ethnobotanical Arch, 3, 84 96 (1981).

18. Anonymous. Phytochemical investigation of certain medicinal plants used in Ayurveda. Central Council for Research in Ayurveda and Siddha, New Delhi, India (1990).

19. Lala P.K., Lab Manuals of Pharmacognosy. CSI Publishers and Distributers, Calcutta, 226 (1993).

20. Adegoke A.A., Iberi P.A., Akinpelu D.A., Aiyegoro O.A. and Mboto C.I., studies on phytochemical screening and antimicrobial potentials of Phyllanthus amarus against multiple antibiotic resistant bacteria. International J. Appl. Res. Nat. Prod. 3(3), 6-12 (2010).

21. Boxi M., Rajesh Y., Kumar V. Raja, Praveen B. andMangamma K., Extraction, phytochemical screening and in-vitro evaluation of anti-oxidant properties of Commicarpuschinesis (aqueous leaf extract). Int. J. Pharm. Biosci., 1, 537-547 (2010).

22. Obianime A.W. and Uche F.I., The phytochemical screening and effects of methanolic extract of Phyllanthus amarus leaf on the biochemical parameters of male guinea pigs. Journal of Applied Sciences and Environmental Management 12 (4), 73-77 (2008).

23. Peach K. and Tracey M.V., Modern Methods of Plant Analysis. Vol. 3, Springer Verlag, Berlin (1956).

24. Allen S.E., Chemical Analysis of Ecological Materials. $\quad\left(2^{\text {nd }} \quad\right.$ ed. $)$ Blackwell Scientific Publications, Oxford. 368pp (1989).

25. You, Q., Chen, F., Wang, X., Luo, P. G., \& Jiang, Y., Inhibitory effects of muscadine anthocyanins on $\alpha$-glucosidase and pancreatic

Egypt. J. Chem. 61, No. 4 (2018) 
lipase activities. Journal of Agricultural and Food Chemistry, 59(17), 9506-9511 (2011).

26. Bonacorsi, C., Raddi, M. S. G., Carlos, I. Z., Sannomiya, M., \&Vilegas, W., Anti-Helicobacter pylori activity and immune stimulatory effect of extracts from Byrsonima crassa Nied .(Malpighiaceae). BMC Complementary and Alternative Medicine, 9(1), 2 (2009).

27. Kawase, M., Motohashi, N., Satoh, K., Sakagami, H., Nakashima, H., Tani, S., Shirataki Y, Kurihara T, Spengler G, Wolfard K, Molnár, J., Biological activity of persimmon (Diospyros kaki) peel extracts. Phytotherapy Research, 17(5), 495-500 (2003).

28. Noruzi, M., Zare, D., \&Davoodi, D., A rapid biosynthesis route for the preparation of gold nanoparticles by aqueous extract of cypress leaves at room temperature. Spectrochimica Acta Part A: Molecular and Biomolecular Spectroscopy, 94, 84-88 (2012).

29. Vilchis-Nestor, A. R., Sánchez-Mendieta, V., Camacho-López, M. A., Gómez-Espinosa, R. M., Camacho-López, M. A., \& Arenas-Alatorre, J. A., Solventless synthesis and optical properties of $\mathrm{Au}$ and $\mathrm{Ag}$ nanoparticles using Camellia sinensis extract. Materials Letters, 62(17-18), 3103-3105 (2008).

30. Song, J. Y., \& Kim, B. S., Rapid biological synthesis of silver nanoparticles using plant leaf extracts. Bioprocess and Biosystems Engineering, 32(1), 79 (2009).

31. Khalil, M.M.H., Ismail, E. H., \& El-Magdoub, F., Biosynthesis of $\mathrm{Au}$ nanoparticles using olive leaf extract: 1st nano updates. Arabian Journal of Chemistry, 5(4), 431-437 (2012).

32. Khalil M.M. H., Sabry, D. Y., \&Khidr, A. S. A., Biosynthesis of gold nanoparticles using Salvia officinalis leaf extract and its microbiological activity. International Journal of Green and Herbal Chemistry Section B, 3, 1668-1678 (2014).

33. Khalil, M.M.H., Mahmoud, I. I., \& Hamed, M. O., Green synthesis of gold nanoparticles using Laurus nobilis L. leaf extract and its antimicrobial activity. International Journal of Green and Herbal Chemistry, Sec. B; 4, 265-279 (2015).

34. Veerasamy, R., Xin, T. Z., Gunasagaran, S., Xiang, T. F. W., Yang, E. F. C., Jeyakumar, N., \& Dhanaraj, S. A., Biosynthesis of silver nanoparticles using mangosteen leaf extract and evaluation of their antimicrobial activities. Journal of Saudi Chemical Society, 15(2), 113-120 (2011).

35. Armendariz, V., Herrera, I., Jose-yacaman, M., Troiani, H., Santiago, P., \& Gardea-Torresdey, J. L., Size controlled gold nanoparticle formation by Avena sativa biomass: use of plants in nanobiotechnology. Journal of Nanoparticle Research, 6(4), 377-382 (2004).

36. Dwivedi, A. D., \& Gopal, K., Biosynthesis of silver and gold nanoparticles using Chenopodium album leaf extract. Colloids and Surfaces A: Physicochemical and Engineering Aspects, 369(13), 27-33 (2010).

37. Kim, K.Y., Nam, K.A., Kurihara, H. and Kim, S.M., Potent alpha-glucosidase inhibitors purified from the red alga Grateloupia elliptica. Phytochemistry., 69, 2820-2825 (2008).

38. Gopinath, V., Priyadarshini, S., MubarakAli, D., Loke, M. F., Thajuddin, N., Alharbi, N. S., Yadavalli, T., Alagiri M., Vadivelu, J. AntiHelicobacter pylori, cytotoxicity and catalytic activity of biosynthesized gold nanoparticles: multifaceted application. Arabian Journal of Chemistry (2016). http://dx.doi.org/10.1016/j. arabjc.2016.02.005

(Received 6/5/2018; accepted 9/6/2018) 


\section{مكافحة البكتريا المضادة للهيليكوباكتر، النشاط المضاد للسكري والسمية للخلايا الحيوية بجسيمات

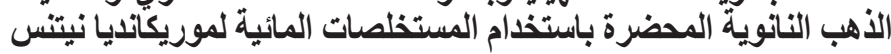

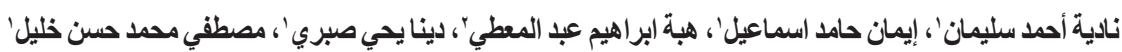

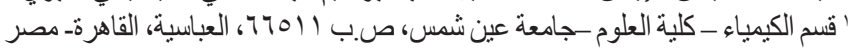

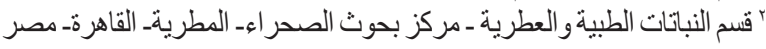

تهذف هذه الدر اسة لتخليق جسيمات الذهب النانونية باستخدام مستخلص المائى لنبات الموركنديا (snetin aidnaciroM)

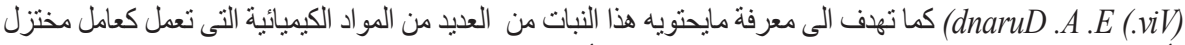

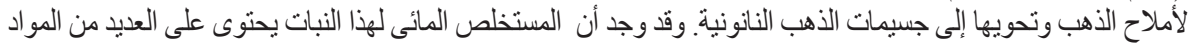

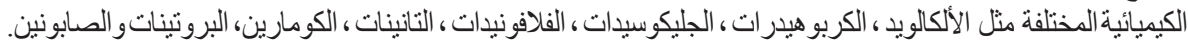

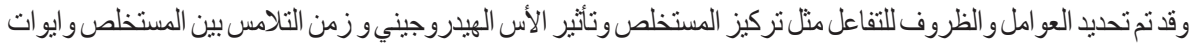

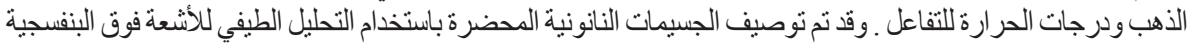
DRX, RITF ، siV-vU

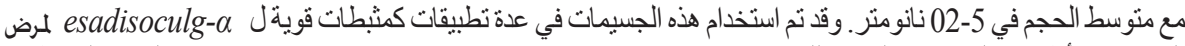
السكر حيث أظهرت الجسيمات النانوية للأهب قيمة

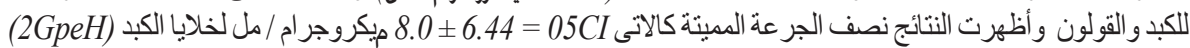

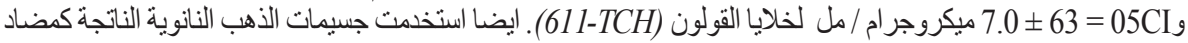
لجرثومة المعدة (irolyp retcabocileH) و أعطت نتائج 52.13 ( 52.13 (ميكروغرام / مل). 